\title{
Fetal Hematic Mummification in a Bitch: Case Report
}

\author{
Miriam de Oliveira Reis ${ }^{1}$, Denise de Mello Bobány ${ }^{2}$, Igor Mansur Muniz ${ }^{3}$, \\ Maria Eduarda Monteiro Silva ${ }^{2}$, Marcelline Santos Luz ${ }^{2}$ \\ ${ }^{I}$ Veterinary practicioner \\ ${ }^{2}$ Professors - Veterinary Medicine-Centro Universitario Serra dos Orgãos - UNIFESO - Teresopolis, RJ Brazil \\ ${ }^{3}$ Professor - Veterinary Medicine- Universidade Federal de Rondônia - Porto Velho, RO Brazil
}

Abstract: Fetal mummification is a very rare condition in dogs that occurs when there is fetal death and the fetus remains hermetically sealed in the uterus, with incomplete resorption. The exact causes have not yet been completely determined, which makes treatment difficult, compromising the female's reproductive system. The paper reports the case of a mixed-breed bitch presenting prolonged gestation, with possible complication. During the castration surgery it was observed that the single fetus was mummified.

Keywords: Canine, pregnancy, fetal changes.

\section{Introdution}

The process of pregnancy begins with the of fertilization of an ovum by spermatozoid. In the bitch, pregnancy has an average variability in 63 days. For the confirmation of pregnancy it is necessary to make use of diagnostic methods such as: palpation, X-ray, ultrasound, among others [1].

The radiographic examination is used to differentiate pregnant bitches of pseudo-gestation or uterine problems and evaluation of fetal development during the final third of gestation. It's also possible detect dystocia, fractures and dislocations that reduce the diameter of the pelvis. In pregnancies most advanced it's possible to find alterations of embryonic death fetal and bone changes, extreme flexing of the body of the fetus, fetal mummification, or emphysematous fetus with presence of gas around it [2].

Ultrasound is the most accurate diagnostic tool for the evaluation of pregnancy and can be used to predict the delivery dates, estimate the number of fetuses as well as observe fetal vital conditions, pathological processes in the uterus and diagnose fetal abnormalities such as maceration, absorption, mummification and delay in fetal development [3].

The behavioral signs in the pre-partum are diverse, and can be observed between two to three days before delivery,when the bitches are usually stressed and, whenever possible, try to hide away, decrease food ingestion and make a nest [4].

In natural birth, the fetus determines the day of delivery, but some parturition may require surgical interventions for the birth of the puppies[4].

The dystocic birth occurs when there is a failure to start the parturition at the right time, or when there are difficulties or impediments to normal expulsion through the uterus [4,5].

Several factors contribute to the dystocia in dogs, including maternal factors and those of fetal origin

The maternal dystocia can be pointed out the pelvic and/or vaginal anomalies, pelvic dislocations, uterine inertia, fractures, osteoarthritis, associated or not to breed and conformation of the bitch [4-6].

The dystocia of fetal origin, you can highlight static anomalous fetal, development fetal aberrations such as fetal maceration, emphysema and fetal mummification, for example [4-6].

Fetal maceration is understood as death of the concept followed by its autolysis, with softening and liquefaction of fetal tissues, leading to a skeletonization [4].

Emphysema of putrefaction rot is characterized by presenting emphysematous changes of the fetus dead and retained in the uterus $[4,6]$.

Fetal mummification occurs though a series of morphological changes that occur with the fetus that is dead and is characterized by dehydration of embryos without decomposition or maceration by being kept hermetically closed within the uterus, preventing contamination $[7,8]$.

According Grunert et al. [7] and Araújo et al. [9], in multiparous females, such as the dog, it is possible to find mummified fetuses, present at the same time in the uterus, wich can be eliminated together during calving.

The exact incidence of embryonic and fetal losses in the bitch and in the cat has had little attention of the researches, being the number report that the exact incidence of losses embryonic and fetal in bitch and cat has had little attention from researchers, and the number of publications limited not only in Brazil but also in other countries [7]. 
Fetal mummification can be classified as papyracea mummification, when the fetus loses its liquid parts, become dry, brownish color, no odor, no pus, with aspect of paper or leather, with its firm consistency, the likeness of a papyrus; bovine hematogenous mummification, linked to a factor lethal recessive, which happens when the fetus has similar manifestations to the mummification papyracea, but between the wall of the uterus and fetal membranes there is a substance of viscous appearance with dark color, adhered to the fetus, whose probable origin is of blood [4,7].

Grunert et al. [7] describe the cases of fetal mummification in bitches are infrequent and consequent death of the fetuses, when the infection in the uterine cavity is unable, due to the cervix remains closed and It may manifest in pregnancy extended and, in cases of abortion, the pregnancy is shortened, and may go unnoticed because the dogs have the habit of burying or eating its products. Its symptoms are not evidente, according Toniollo; Vicente [4], but we can check dystocia, due to adhesion of the fetus to the uterus in females multiparous female.

General symptoms such as anorexia or capricious appetite with progressive weight loss, anemia and a decrease of by are described by Grunert et al. [7].

The criteria for diagnosis of dystocia are: prolonged gestation without signs of labor, vaginal secretion for more than 2 to 3 hours, contractions without expulsion of the fetus, anamnesis information, and palpation of the flanks when it is possible to detect compact or floating formations circumscribed $[4,7,10]$.

The diagnosis must be complemented by X-ray and/or abdominal ultrasound. By ultrasound, valuable information in the evaluation of pregnancy may be disclosed as well as diagnosed fetal abnormalities in different degrees of involvement (for the fetus, the brood and/or the pregnant female) including dead fetuses and in the process of mummification or maceration [11].

According Toniollo, Vicente [4], the prognosis is normally favorable for the life of the female and unfavorable to the reproduction. In companion animals, although the animal will be discarded from reproduction, the ovariosalpingohisterectomia is the better treatment indicated. However, if it is desired to preserve the reproductive capacity of the female, one can try to drug treatments aimed at the elimination of the contents of the uterus, with manual removal of the fetus through the vagina or via cesareana $[4,7]$.

\section{Case Report And Discussion}

A 6-year-old Maltese breed bitch, golden color coat, was seen in the Clinic-School of Veterinary Medicine of UNIFESO with a 64-day of gestation, and no signs of labor, agreeing with the characteristics presented by Grunert et al. [7] (figure 1).

Through palpation, it was observed that the bitch had small abdominal volume, dilated vulva and undeveloped mammary gland, symptoms that did not allow to evidence pregnancy or any disorder, which confirms the description of Toniollo; Vicente [4], Grunert et al. [7] and Cruz et al. [12].

Due to personal circumstances, the owner didn't want to do the ultrasound, which would contribute with valuable information about the pregnancy and could diagnose fetal mummification, as say Teixeira; Wischral [11], preferring to carry out castration.

During ovariosalpingohisterectomia surgery, better treatment indicated for problems of mummified fetus according to Toniollo; Vicente [4] and Grunert et al. [7], a single fetus was observed in the right uterine horn, witch was increased (figure 2).

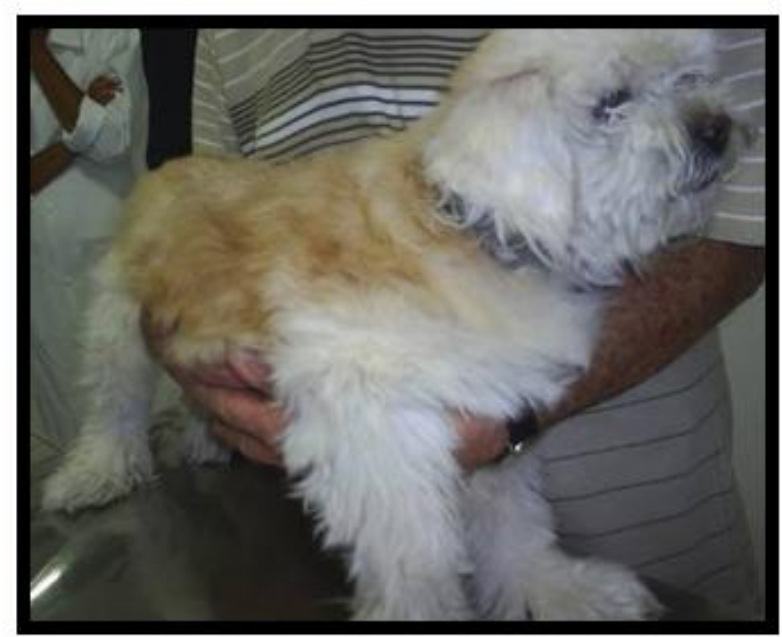

Figure 1 - Dog Breed during care at the clinic and School of Unifeso

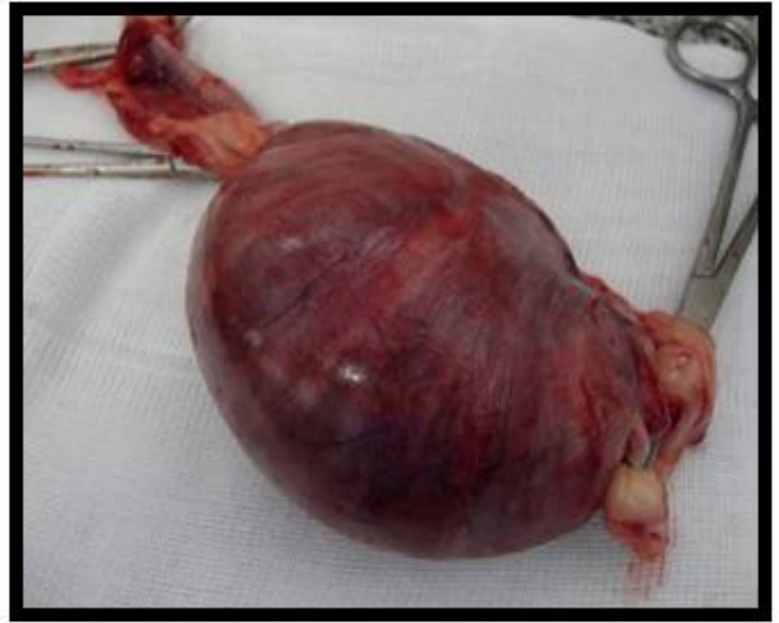

Figure 2 - Aspect of the uterine hom pregnancy 
The appearance of the fetus was resected and brownish and had a gelatinous substance, viscous appearance with dark color adhered to the fetus (figures 3 and 4) what agrees with the description of hematogenous mummification, although this type is more common in cattle breed Guernsey linked to one factor recessive lethal in accordance with Toniollo; Vicente [4] e Grunert et al. [7].

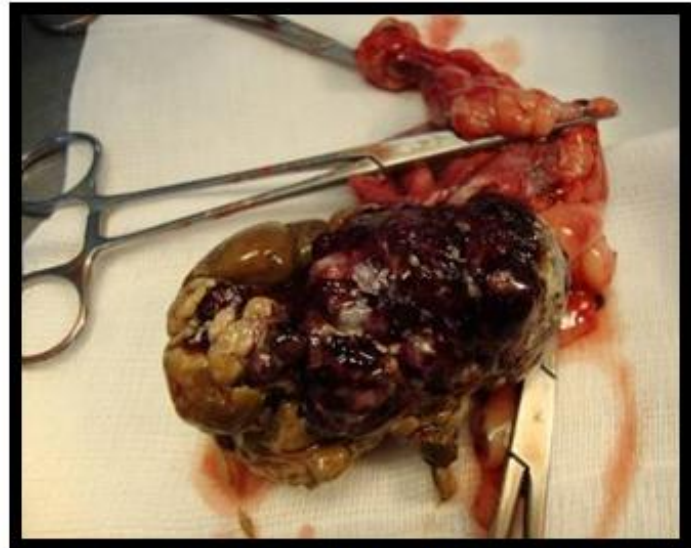

Figure 3 -Mummified fetus presenting substance of dark color

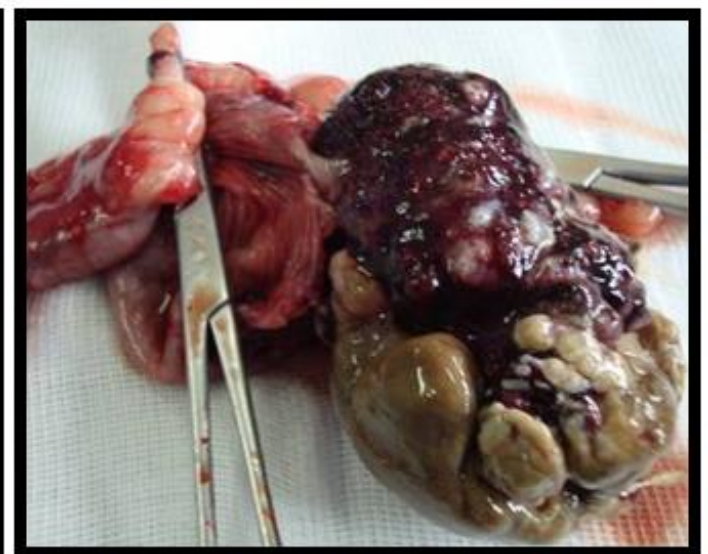

Figure 4 - Brownish-colored fetus adhered to placental debris and uterine wall

\section{Conclusions}

It was verified that, although the female did not present some physical sign that could evidence its gestation, by clinical examination through palpation, it was possible to feel an abdominal volume, which generated the diagnostic suspicion of pregnancy with the possibility of the fetus not being alive, due to the prolongation of gestation.

The single fetus underwent blood mummification, described more frequently in cattle.

Because it is a rare case in the small clinic, the follow-up of this case becomes an additional contribution to the scientific community since it confirms, in the canine species, all the annotations made by the few authors that approached the subject.

\section{References}

[1] T.I.R. Costa, Urgências reprodutivas na cadela, masters diss. Universidade Técnica De Lisboa, Lisboa, Portugal, 2010.

[2] M.M. Baba, Diagnóstico de gestação em cadelas: aspectos radiográficos e ultrassonográficos, graduation monog. Faculdade de Medicina Veterinária e Zootecnia da Universidade "Júlio de Mesquita Filho", Botucatu, SP, 2010

[3] D. C. Gomes, Principais alterações ultra-sonográficas do sistema reprodutor canino. doctoral diss. Universidade Estadual Paulista "Júlio de Mesquita Filho" Faculdade de Medicina Veterinária e Zootecnia, Botucatu, SP, 2008

[4] G. H. Toniollo, W. R. R. Vicente, Manual de obstetrícia veterinária (São Paulo: Livraria Varela, 2003).

[5] M.R. Luz, P. M. C. Freitas, E. Z. Pereira, Gestação e parto em cadelas: fisiologia, diagnóstico de gestação e tratamento das distocias, Rev Bras Reprod Anim, 29(3/4), 2005,142-150.

[6] C. Y. Kagiyama, Afecções do útero gravideo, graduation monog. CENTRO UNIVESITARIO FMU, São Paulo, SP, 2010.

[7] E. Grunert, E.H. Birgel, W.G. Vale, E.H.B. Junior, Patologia e clínica da reprodução dos animais domésticos (São Paulo: Livraria Varela, 2005).

[8] J. Sandoval-Castilho, C. Villavicencio-Garayzar, Fetal mummification in silky shark (Carcharhinus falciformis) from the Gulf of California, Mexico, Braz. arch. biol. Technol, 51(3), 2008.

[9] A. A. Araújo, A. F. Brasil, A. A. A. N. Moura, A. C. B. Lima, Fetal mummification in a cow with twin gestation and retention of the fetuses in the vagina: a case report, Revista Ciência Agronômica, 37(1), 2006, 113-116.

[10] R. Rabelo, Emergências em Pequenos Animais: Condutas Clínicas e Cirúrgicas no Paciente Grave (Rio de Janeiro: Elsevier Brasil, 2012).

[11] M.J.D. Teixeira, A. Wischral, Avaliação do desenvolvimento fetal e acompanhamento da gestação e parto pela ultra-sonografia em cadelas. Rev Bras Reprod Anim, 32(1), 2008,16-20.

[12] T.P.P.S. Cruz, S.R. Lima, D.R.P. Travagin, C.A. Pescador, R.L. Souza, Ovarian and Uterine Horn Agenesis Accompanied by Ectopic Fetal Mummification in Canine. Acta Scientiae Veterinariae 44(1), 2016, 139. 